\title{
Variations in the 2004 Indian Ocean tsunami deposits thickness and their preservation potential, southwestern Thailand
}

\author{
Kazuhisa Goto $^{1 *}$, Jun Takahashi ${ }^{1 \dagger}$, and Shigehiro Fujino ${ }^{2 \ddagger}$ \\ ${ }^{1}$ Disaster Control Research Center, Graduate School of Engineering, Tohoku University, Sendai 980-8578, Japan \\ ${ }^{2}$ Active Fault and Earthquake Research Center, National Institute of Advanced Industrial Science and Technology (AIST), \\ Site C7 1-1-1 Higashi, Tsukuba 305-8567, Japan
}

(Received November 29, 2010; Revised August 25, 2011; Accepted August 26, 2011; Online published October 24, 2012)

\begin{abstract}
Field surveys were conducted in March 2005 and December 2008 in southwestern Thailand to investigate local variation in the thickness and preservation potential of onshore deposits formed by the 26 December 2004 Indian Ocean tsunami. The 2008 survey results revealed that the thickness of deposits varies by a few centimeters in pits located less than $10 \mathrm{~m}$ apart because of local undulation of the topography and possible bioturbation. At 13 among all 24 sites, the difference in thickness during 2005 and 2008 surveys was within the range of local variation. In fact, very thin tsunami deposits with $1 \mathrm{~cm}$ thickness in the 2005 survey were well preserved during the 2008 survey. Furthermore, tsunami deposits near the maximum inundation limit were found in the 2008 survey, with thicknesses that are consistent with those reported from the 2005 survey. At no site was a tsunami deposit eliminated completely. Based on these observations, we infer that the tsunami deposit thickness is well preserved, even in a tropical climate with heavy rains such as that of Thailand.
\end{abstract}

Key words: The 2004 Indian Ocean tsunami, tsunami deposit, preservation, local variation, Thailand.

\section{Introduction}

On 26 December 2004, one of the largest tsunamis in human history (the 2004 Indian Ocean tsunami (IOT)) struck coastal areas of countries surrounding the Indian Ocean. The tsunami brought many severe consequences, including human injury and death, damage to buildings, coastal erosion, and degradation of marine and coastal ecosystems. The tsunami removed sediments from the sea bottom and beaches, and transported them landward and/or seaward. Consequently, severe coastal erosion occurred in those Indian Ocean countries (Kench et al., 2006; Choowong et al., 2009; Goto et al., 2011). In addition, fisheries and agricultural areas were damaged severely by seawater inundation or by burial under salty sediments (e.g. Szczuciński et al., 2005).

Onshore and offshore tsunami deposits formed by the 2004 IOT are regarded as modern analogues to elucidate characteristics of the paleo-tsunami deposits and aid in identification of prehistorical and geological tsunami events (e.g. Dawson and Stewart, 2007). In fact, many researchers have examined tsunami deposits formed by the 2004 IOT

*Present address: Planetary Exploration Research Center, Chiba Institute of Technology, 2-17-1 Tsudanuma, Narashino 275-0016, Japan.

${ }^{\dagger}$ Present address: Tohoku Electric Power Co. Inc., 1-7-1 Honcho, Aoba-ku, Sendai 980-8550, Japan.

$\ddagger$ Present address: Graduate School of Life and Environmental Sciences, University of Tsukuba, 1-1-1 Tennodai, Tsukuba 305-8572, Japan.

Copyright (c) The Society of Geomagnetism and Earth, Planetary and Space Sciences (SGEPSS); The Seismological Society of Japan; The Volcanological Society of Japan; The Geodetic Society of Japan; The Japanese Society for Planetary Sciences; TERRAPUB

doi:10.5047/eps.2011.08.019 and earlier deposits to investigate their sedimentary features (e.g., Moore et al., 2006; Szczuciński et al., 2006; Bahlburg and Weiss, 2007; Goto et al., 2007, 2008; Hawkes et al., 2007; Hori et al., 2007; Umitsu et al., 2007; Choowong et al., 2008a, b; Fujino et al., 2008; Matsumoto et al., 2008; Morton et al., 2008), the recurrence interval of huge tsunami in the Indian Ocean (Jankaew et al., 2008; Monecke et al., 2008; Fujino et al., 2009), and the impact and recovery processes of the coastal geomorphology (Choowong et al., 2009; Goto et al., 2011).

The 2004 IOT deposits provide an opportunity to study its flow conditions and the variation in its preservation by examination of the deposits' thickness, grain size, and sedimentary features (e.g. Szczuciński et al., 2006). Results of such studies will continue to contribute to identification of paleo-tsunami deposits (e.g., Jankaew et al., 2008; Fujino et al., 2009), and contribute to estimation of the flow conditions of paleo-tsunami from characteristics of onshore tsunami deposits such as the thickness, grain size, and sedimentary features (e.g., Jaffe and Gelfenbaum, 2007; Moore et al., 2007). However, very few studies of the preservation potential of the tsunami deposits have been reported to date, especially in terms of the variation in thickness, even for the 2004 IOT case (Kench et al., 2006, 2008; Szczuciński et al., 2006, 2007; Goto et al., 2008; Nichol and Kench, 2008; Szczuciński, in press).

Kench et al. (2006, 2008) and Nichol and Kench (2008) studied the 2004 IOT deposits at the Maldives and reported that sand sheets and lobes are unlikely to be preserved as recognizable tsunami layers because the sand sheets are extremely thin (average of $1 \mathrm{~cm}$ ) in those research fields. They further noted that pedogenic processes and bioturbation are 


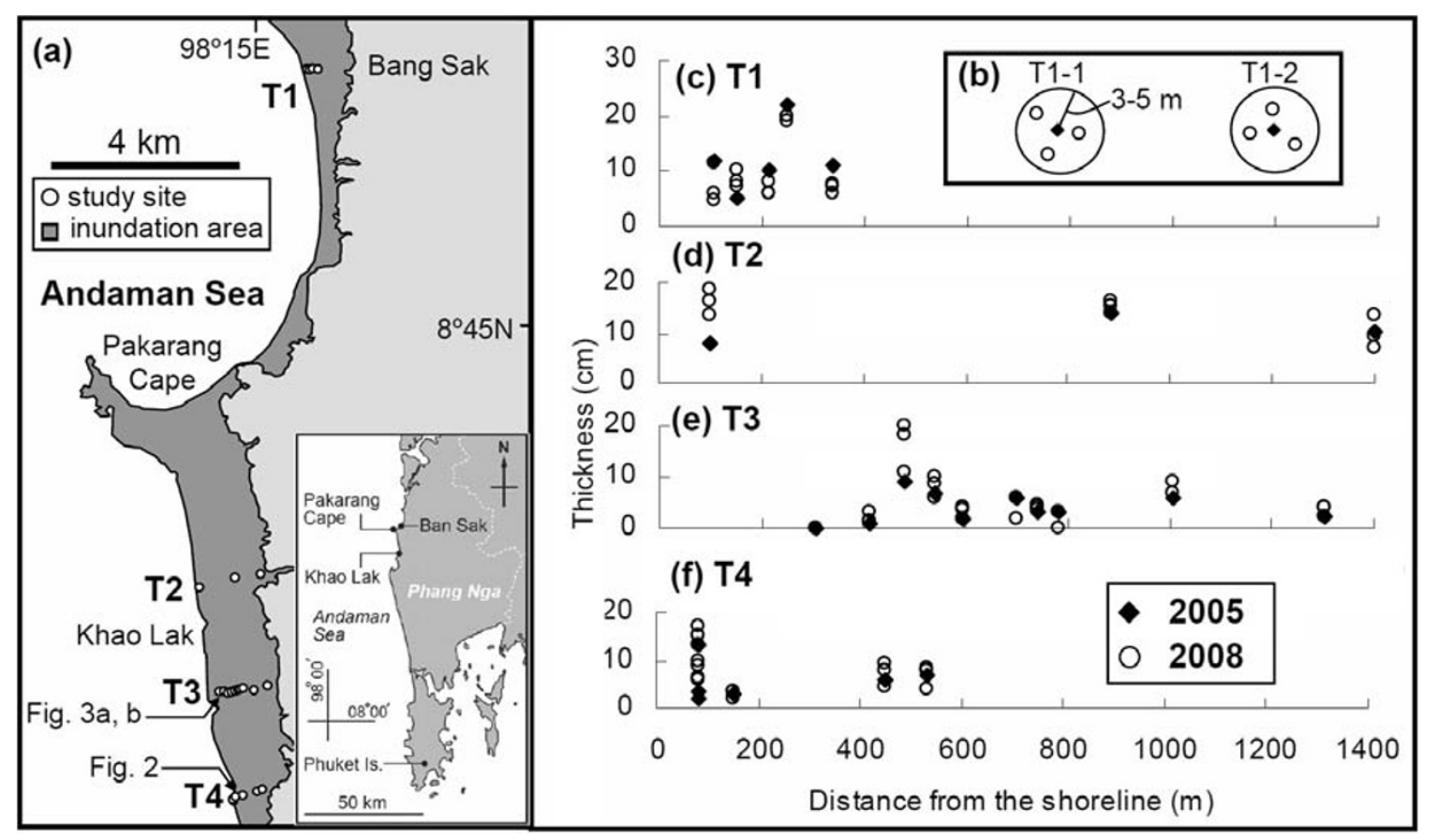

Fig. 1. (a) Map showing the tsunami inundation area and the studied sites in southwestern Thailand. The coastline shows the low-tide line. (b) Schematic diagram showing the survey pits at 2005 and 2008 surveys. The 2008 pits (white circle, 3 pits at each site) are located within $3-5$ m in radius from the 2005 pit (black diamond). (c-f) Thickness of the tsunami deposits during 2005 and 2008-2009 surveys along transects (c) T1 (= transect B of Goto et al., 2008), (d) T2 (= transect K1 of Fujino et al., 2008), (e) T3 (= transect K2 of Fujino et al., 2008 ), and (f) T4 (= transect K3 of Fujino et al., 2008).

likely to mix the sediments vertically. Goto et al. (2008) investigated the tsunami deposits at the southwestern coast of Thailand and reported that the thickness of the tsunami deposits measured in September 2005 had decreased, becoming about $70 \%$ of the thickness measured in March 2005. Szczuciński (in press) reported detailed results related to the preservation potential of the onshore tsunami deposits at southwestern Thailand. He reinvestigated pits along transects shortly after the tsunami and after one, two, three, and four years, and reported that the tsunami deposits were preserved after four years at only half of the studied sites because of human activities or new soil formation. He also reported that tsunami deposits with thickness of at least a few centimeters were well preserved. In this way, the preservation potential of the tsunami deposit thickness remains uncertain because of the scarcity of data.

Investigation of the preservation potential presents technical challenges. For example, local variation of the thickness of the tsunami deposits, which is observed between the pits of few meters in horizontal scale, caused by undulation of the topography, is an important factor to interpret the preservation potential of the deposits. In fact, the tsunami deposit thickness is known to be highly variable with several to several tens of centimeters' thickness, depending on local undulation (Hori et al., 2007; Fujino et al., 2010; Naruse et al., 2010). To study the preservation potential, a pit in the same place as that examined before should be avoided because the deposits were disturbed during prior digging and covered with other soil (Szczuciński, in press), which in turn suggests that it is not possible to study exactly the same pits, although pits in very close proximity should be studied to compare the preservation potential and thickness variation. Therefore, local variation in thickness, which is of a few meters in horizontal scale, must be considered to investigate the preservation potential of tsunami deposits.

This study was undertaken to ascertain the effects of local variation of the thickness of the tsunami deposits and to elucidate the preservation potential of tsunami deposits.

\section{Impact of the 2004 Indian Ocean Tsunami at Thailand}

In 2004, a tsunami struck the southwestern coast of Thailand facing the Andaman Sea, causing approximately 8,300 casualties (e.g. Satake et al., 2007). Wave heights of more than $5 \mathrm{~m}$ were commonly reported, but a maximum height of $19.6 \mathrm{~m}$ was recorded at Phra Thong Island in Phangnga Province (Tsuji et al., 2006). A strand plain extends between Khao Lak and Bang Sak areas (Fig. 1(a)), where our studied area is located (Fujino et al., 2010). Most of the lowlands around Khao Lak have similar topography. The strips of land are no more than 2-3 km wide and 4$5 \mathrm{~m}$ above sea level (Hori et al., 2007). In this area, the tsunami height generally exceeded $5 \mathrm{~m}$ and reached a maximum of $12 \mathrm{~m}$, with inundation extending about $2 \mathrm{~km}$ inland (Matsutomi et al., 2006; Tsuji et al., 2006; Goto et al., 2007, 2008; Yanagisawa et al., 2009).

In Thailand, tsunami-related erosion and sedimentation were reported both onshore (e.g., Szczuciński et al., 2006; Choowong et al., 2007, 2009; Hawkes et al., 2007; Hori et al., 2007; Kelletat et al., 2007; Umitsu et al., 2007; Fagherazzi and Du, 2008; Fujino et al., 2008, 2010; Goto et al., 2008; Matsumoto et al., 2008; Sawai et al., 2009; Yawsangratt et al., 2009; Naruse et al., 2010) and offshore 
(Chavanich et al., 2005; Feldens et al., 2009; Sugawara et al., 2009). Thicknesses of the onshore tsunami deposits were as great as $60 \mathrm{~cm}$ (Szczuciński, in press). Generally the thickness and grain size respectively showed thinning and fining landward, although they were highly variable depending on the local undulation of the topography (e.g., Hori et al., 2007; Fujino et al., 2008; Szczuciński, in press) and hydrodynamic features of the tsunami.

\section{Study Area and Methods}

\subsection{Study area and review of the $\mathbf{2 0 0 5}$ survey results}

To examine the local variation of the thickness and the preservation potential of the tsunami deposits, we selected the following four transects: one transect at Bang Sak (transect B of Goto et al., 2008) and three transects at Khao Lak (transects K1, K2, and K3 of Fujino et al., 2008, 2010) (Fig. 1). As Fig. 1 shows, we renamed these from north to south as transects 1-4 (T1-T4). Our survey sites at each transect were numbered therefore in a landward direction (e.g., we named T1-1, T1-2 ... T1-5 from shore to land). Tsunami deposits along these transects were studied in March 2005 by Goto et al. (2008) (T1) and Fujino et al. $(2008,2010)(\mathrm{T} 2-\mathrm{T} 4)$ (hereinafter we designate those efforts as the 2005 survey).

Along T1-T4, the beach ridge of about $4-5 \mathrm{~m}$ in elevation developed behind the beach. Its peak is situated around $100 \mathrm{~m}$ in horizontal distance from the shoreline (e.g., Hori et al., 2007; Goto et al., 2008). Behind the ridge, the topography is very flat, although minor undulations of up to several tens of centimeters were observed elsewhere in the studied area (Goto et al., 2008).

Along T1 at Bang Sak, Goto et al. (2008) studied tsunami deposits in five pits. Severe erosion was dominant near the beach, although sandy tsunami deposits up to $22-\mathrm{cm}$ thick were widely distributed between $50 \mathrm{~m}$ and $300 \mathrm{~m}$ from the shoreline. The thickness of the tsunami deposit varies significantly, and its landward thinning is not apparent.

Fujino et al. $(2008,2010)$ studied 23 pits along transects T2-T4. Tsunami deposits show large variations in thickness, although the deposit generally thins toward the landward limit of inundation (Fujino et al., 2010). The thickness of the tsunami deposits close to the shoreline is generally less than $10 \mathrm{~cm}$ (up to $20 \mathrm{~cm}$ ), decreasing to $1 \mathrm{~cm}$ near the landward limit of inundation. Larger fluctuations of thickness and the lack of a clear landward-fining trend in grain size can be attributed to the irregular landforms in the area. Local surface concavities and convexities might have affected the tsunami flow, consequently resulting in differences in thickness by more than a few centimeters (Fujino et al., 2010).

Transects T1-T4 are suitable for the study of the preservation potential as well as the local variation of the thickness of the tsunami deposits because (1) the 2005 surveys were conducted soon after the tsunami but before the beginning of the rainy season, which starts from May. Consequently, it is possible to infer that the thickness of the tsunami deposits measured during these surveys was not modified greatly by post-tsunami natural and human disturbances, and (2) these transects were located in weeded blank spaces (Khao Lak area) or a private coconut farm
(Bang Sak area). Therefore, the disturbance of the ground by human activity after the tsunami has not been great, except at a few sites.

\subsection{Methods}

We reinvestigated the tsunami deposit thickness at 24 sites along T1-T4 during 18-22 December, 2008 (hereinafter designated as the 2008 survey) with some additional work conducted during 10-12 November, 2009. We did not investigate four sites along $\mathrm{T} 2$ and $\mathrm{T} 4$ because these sites were inaccessible or because artificial structures such as houses had been built. The area ranging from the shoreline to $100 \mathrm{~m}$ inland at transects T2 and T4 (T2-1 and T4-1, 2,3 ) has several shops for tourists along the seaward and landward slopes of the beach ridge (Fig. 2).

Using hand-held GPS, we approached the survey sites. It is noteworthy that hand-held GPS devices have a horizontal error of 3-5 m. Therefore, it is difficult to re-measure the thickness of the tsunami deposits at exactly the same pits as those used for measurements during the 2005 survey. Moreover, a pit in the same place as before should be avoided when assessing the preservation potential. For those reasons, local variation should be studied as well. To investigate the local variation of the thickness of the tsunami deposits, we measured the thickness at three different points within a 10-m-diameter area of each studied site (Fig. 1(b)). Within the area, local undulations were very minor-of centimeter order-as inferred from visual inspection. We used a 60-cm-long hand-held Geoslicer (Fukken Co. Ltd., Hiroshima, Japan) and a peat sampler $(50 \mathrm{~cm}$ long) to obtain undisturbed samples for measurements of the tsunami deposit thickness. A hand-held Geoslicer is a sampling tool used to extract undisturbed subsurface sediments: an oriented sediment core of $6 \mathrm{~cm}$ width, $3 \mathrm{~cm}$ thickness, and $60 \mathrm{~cm}$ length can be extracted (Takada et al., 2002). We measured the tsunami deposit thickness at $5 \mathrm{~mm}$ resolution.

Our results reported for the 2008 survey include the following errors and uncertainties, which might affect the interpretation of the local variation and preservation potential of the tsunami deposits: (1) natural disturbances (e.g., rain, water flow, and bioturbation), (2) human activities, (3)

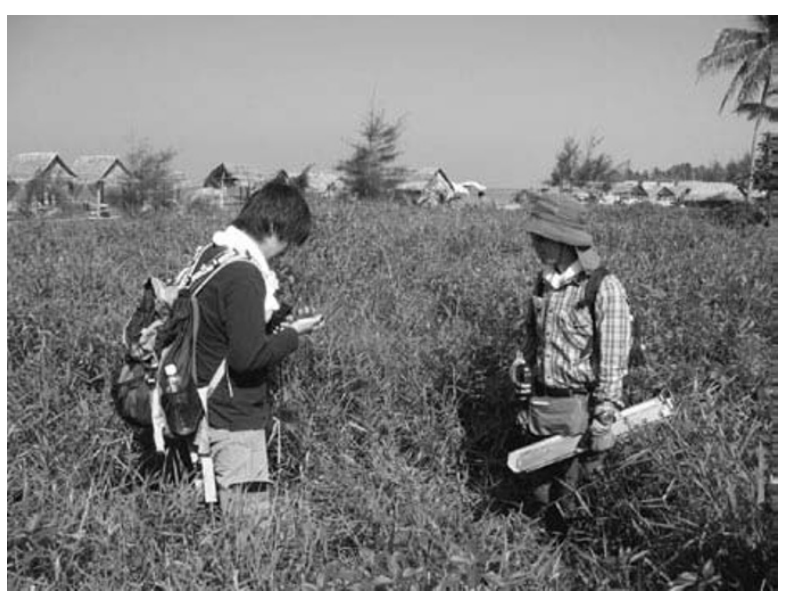

Fig. 2. Photograph taken on 2008 close to the shoreline of the T4 (near T4-2 site). Very high vegetation at the site and several shops are observed along the beach. 


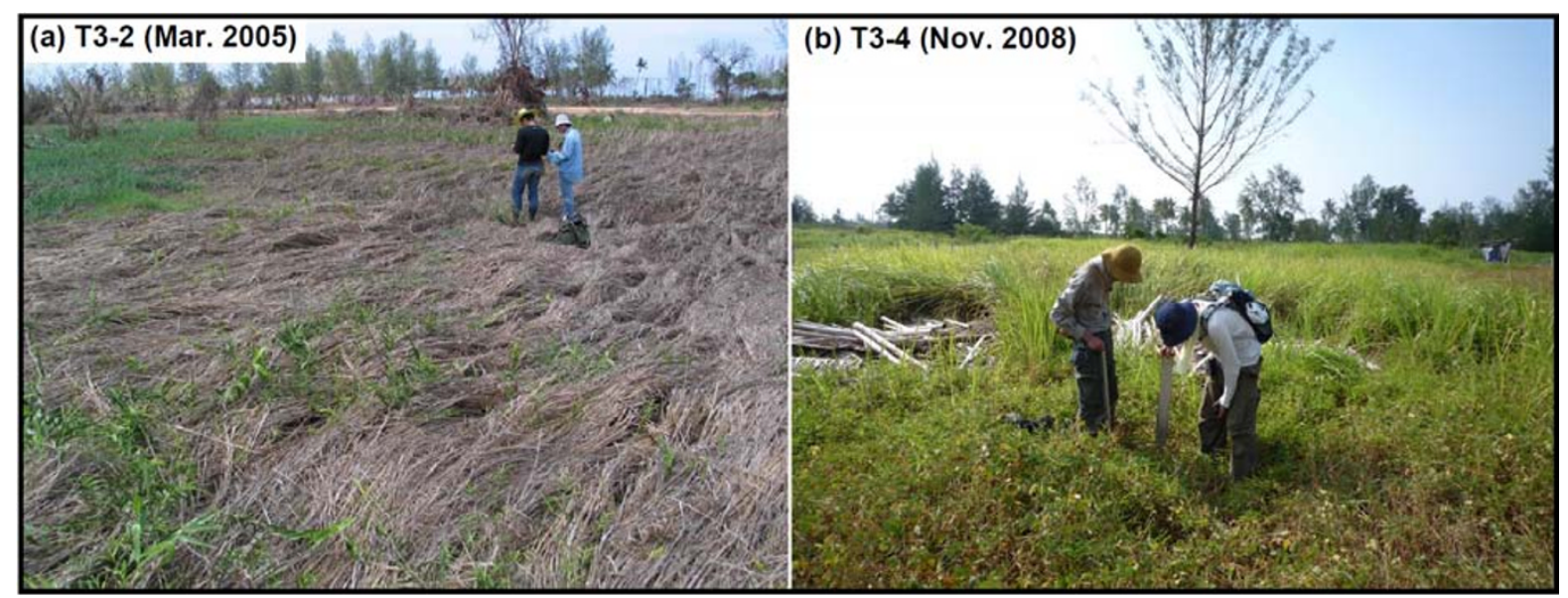

Fig. 3. Photographs taken along transect T3 in (a) March 2005 (grass was flipped toward the sea as indicator of return flow) and (b) November 2008.

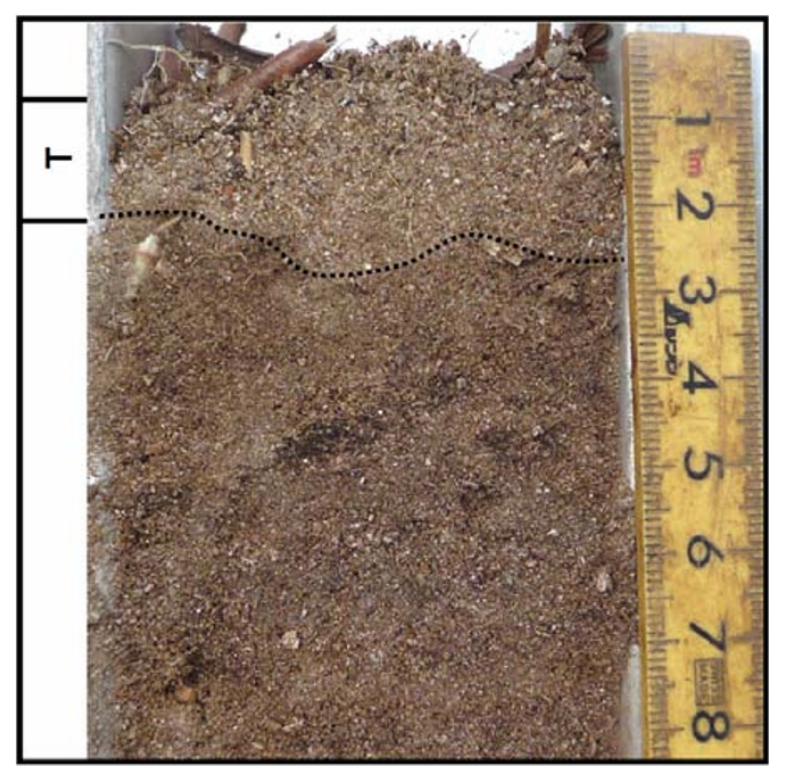

Fig. 4. Tsunami deposits at T3-2. A very thin tsunami deposit was preserved. T: tsunami deposit.

slightly different survey points during 2005 and 2008 survey because of accuracy of GPS, and (4) difference of the measurement method (pit vs. Geoslicer).

\section{Results of the 2008 Survey}

The landscape of the studied sites changed drastically between the 2005 and 2008 survey. During the 2005 survey, the ground was covered by sediment, debris, artificial objects, and grass, the latter of which was bent and withered because of the tsunami (Fig. 3(a)). However, during the 2008 survey, the ground was fully covered by dense vegetation with high plants of up to $60-70 \mathrm{~cm}$ height (Figs. 2 and 3(b)). This vegetation made it difficult to reach the target sites, which in turn suggests that dense vegetation keeps humans from disturbing weeded areas and that it has contributed to preserve the tsunami deposits from disturbance by humans.

Tsunami deposits were well preserved, independent of their thicknesses and location. In fact, even a very thin deposit of $1 \mathrm{~cm}$ thickness measured during the 2005 survey was well preserved $(1.5-3 \mathrm{~cm}$ during the 2008 survey, Fig. 4). Tsunami deposits were covered by the thin (few centimeters' thickness) post-tsunami brownish soil with sand (Fig. 5). At no site had tsunami deposits been removed completely (Table 1).

Sedimentary structures and the grain size of each pit are generally equal to that studied in the 2005 survey by Fujino et al. (2008, 2010) and Goto et al. (2008). On the other hand, tsunami deposits were sometimes disturbed by plant roots (Fig. 5(a)). Internal sedimentary structures were disturbed when the original thickness of the tsunami deposits was of centimeter order. However, as presented in Fig. 5(b), sedimentary structures such as layering of the coarse and fine sands were well preserved if the tsunami deposits were more than 10 centimeters thick. However, even for such thick deposits, the upper few centimeters were generally disturbed by roots or by animals and insects.

Thicknesses of the tsunami deposits at three different points at each site within $10 \mathrm{~m}$ diameter were varied, as presented in Table 1 and the error bar in Fig. 6. The local thickness variation at each site was as great as $9 \mathrm{~cm}$.

Even for the Geoslicer width $(6 \mathrm{~cm})$, the thickness of the tsunami deposits varies ca. 1-2 cm depending on where the thickness is measured. Moreover, the boundary between the tsunami deposit and the post-tsunami soils is generally indistinct, probably because the post-tsunami soil mostly comprises tsunami deposits that are rich in organic matter. Therefore, our thickness measurements probably include measurement error, but that error is inferred as less than $2 \mathrm{~cm}$.

\section{Discussion}

\subsection{Local variation of the tsunami deposits}

Our 2008 survey results clarified that the variation in thickness has changed even within $10 \mathrm{~m}$ interval between pits along the transect. However, such local variation in thickness is no greater than $9 \mathrm{~cm}$ (Fig. 6). At 12 sites, the variation is less than $2 \mathrm{~cm}$, which is close to the measurement error $(<2 \mathrm{~cm})$. At the other 12 sites, the variation is explainable by the local undulation of the topography or bottom erosion by the tsunami. In fact, it is reported that 


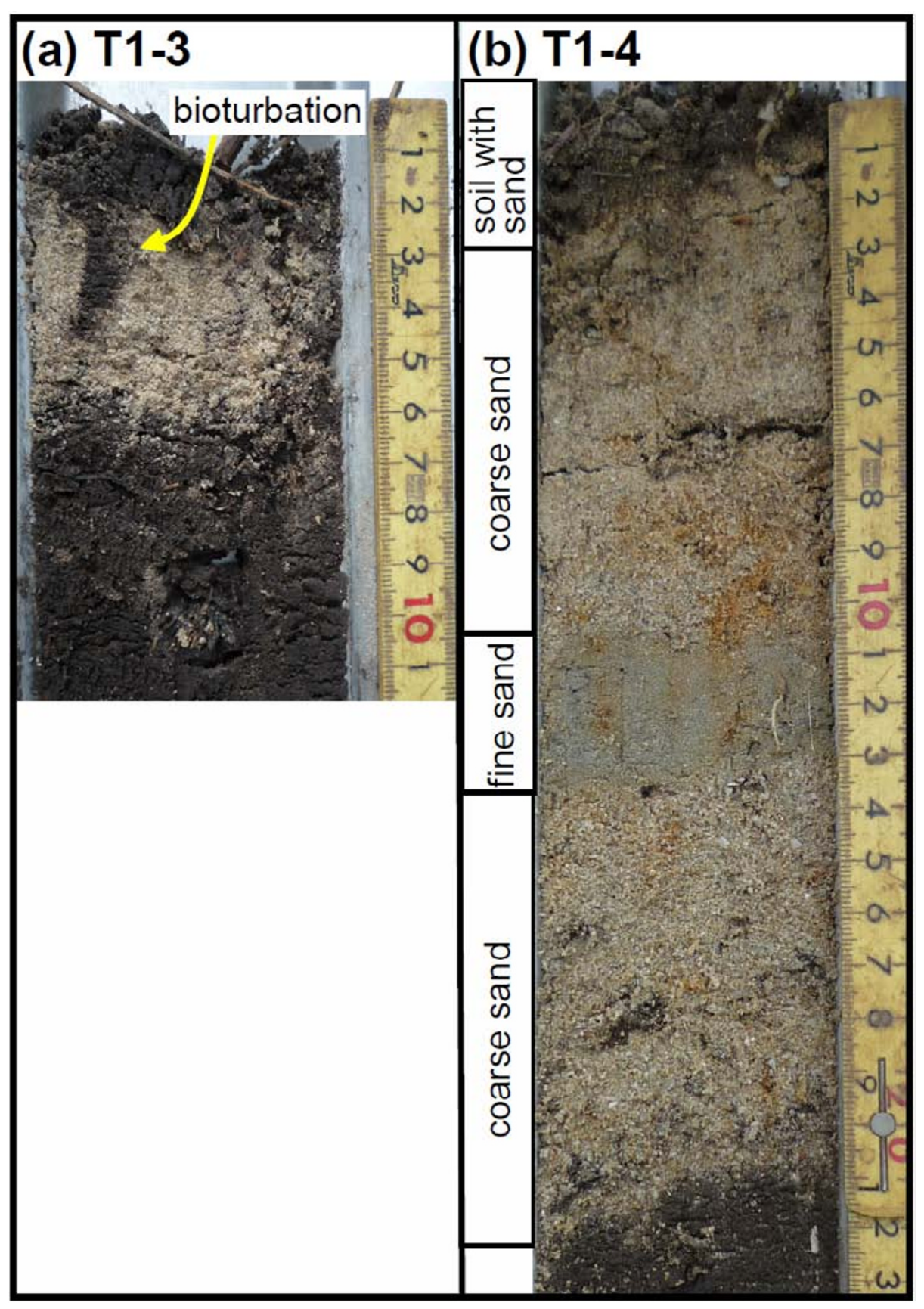

Fig. 5. Tsunami deposits at (a) T1-3, and (b) T1-4.

the thicker tsunami deposits were formed in topographic depressions, and that thin deposits were formed at topographic high areas such as at the top of the ridge (e.g. Hori et al., 2007). Naruse et al. (2010) studied the variation of the sedimentary features and the thickness of the tsunami deposit at Thailand by observing a $2.5 \mathrm{~m}$ wide trench. They found that the thickness varies a few centimeters within the trench. Such very local variation in thickness might result from local undulation of the topography or local bottom erosion by the tsunami, etc. (Naruse et al., 2010).

\subsection{Implications for the preservation potential of the tsunami deposits}

As explained above, investigation of the preservation potential of the tsunami deposits is hampered by technical problems and local variation of the tsunami deposits (see also Szczuciński, in press). Nevertheless, our results suggest that, at 13 of the total 24 sites, the differences in thickness during 2005 and 2008 surveys were within the range of the local variation that was measured during the 2008 survey (Figs. 1 and 6). In addition, at another seven sites, the difference is beyond the range of the local variation of the thickness measured at the 2008 survey, but it is only less than $2 \mathrm{~cm}$. Such a very minor difference in thickness is probably explained by the local undulation of the topography, local bottom erosion by the tsunami, and measurement error. Therefore, we infer that the tsunami deposits at these 20 sites (about $80 \%$ of all sites) are well preserved with respect to the layer thickness. Apparent thinning of more than $3.5 \mathrm{~cm}$ of the thickness was observed only at one site (T15). This thinning might be attributable to post-tsunami ero- 
Table 1. Thickness data of the tsunami deposits at 2005 and 2008 surveys.

\begin{tabular}{|c|c|c|c|c|c|c|c|c|c|}
\hline \multirow[t]{2}{*}{$\begin{array}{c}\text { Site } \\
\text { number }\end{array}$} & \multirow[t]{2}{*}{ Area } & \multirow[t]{2}{*}{ Latitude } & \multirow[t]{2}{*}{ Longitude } & \multirow[t]{2}{*}{$\begin{array}{l}\text { Thickness in } \\
2005(\mathrm{~cm})\end{array}$} & \multicolumn{3}{|c|}{$\begin{array}{l}\text { Thickness in } 2008 \\
\text { and } 2009(\mathrm{~cm})^{* 2}\end{array}$} & \multirow[t]{2}{*}{$\begin{array}{l}\text { Average } \\
(\mathrm{cm})\end{array}$} & \multirow[t]{2}{*}{$\begin{array}{l}\text { Distance from } \\
\text { shoreline }(\mathrm{m})^{* 3}\end{array}$} \\
\hline & & & & & First & Second & Third & & \\
\hline $\mathrm{T} 1-2$ & Bang Sak & 8.7996 & 98.2606 & 5 & 7 & 8 & 10 & 8.3 & 152 \\
\hline T1-3 & Bang Sak & 8.7996 & 98.2612 & 10 & 6 & 6 & 8 & 6.7 & 215 \\
\hline $\mathrm{T} 2-1$ & Khao Lak & 8.6962 & 98.2424 & 8 & 13.5 & 16.5 & 18.5 & 16.2 & 99 \\
\hline $\mathrm{T} 2-2$ & Khao Lak & 8.6980 & 98.2494 & 14 & 14 & 15.5 & 16.5 & 15.3 & 885 \\
\hline $\mathrm{T} 2-3$ & Khao Lak & 8.6988 & 98.2540 & 10.3 & 7 & 9.5 & 13.5 & 10.0 & 1400 \\
\hline T3-1 & Khao Lak & 8.6757 & 98.2466 & 0 & 0 & 0 & 0 & 0.0 & 306 \\
\hline T3-6 & Khao Lak & 8.6763 & 98.2502 & 6 & 2 & 6 & 6 & 4.7 & 698 \\
\hline T3-7 & Khao Lak & 8.6764 & 98.2506 & 3 & 3.5 & 4 & 4.5 & 4.0 & 739 \\
\hline T3-8 & Khao Lak & 8.6767 & 98.2510 & 3 & 0 & 3 & 3 & 2.0 & 781 \\
\hline T3-9 & Khao Lak & 8.6766 & 98.2530 & 6 & 7 & 9 & N/A*1 & 8.0 & 1005 \\
\hline T3-10 & Khao Lak & 8.6767 & 98.2529 & 2.5 & 2.5 & 4 & 4 & 3.5 & 1304 \\
\hline $\mathrm{T} 4-1$ & Khao Lak & 8.6547 & 98.2496 & 3.5 & 10 & 13 & 17 & 13.3 & 82 \\
\hline $\mathrm{T} 4-2$ & Khao Lak & 8.6554 & 98.2494 & 2 & 6 & 6.5 & 9 & 7.2 & 82 \\
\hline $\mathrm{T} 4-3$ & Khao Lak & 8.6559 & 98.2492 & 13 & 13 & 15 & 15 & 14.3 & 81 \\
\hline $\mathrm{T} 4-4$ & Khao Lak & 8.6560 & 98.2499 & 3 & 2 & 3.5 & 3.5 & 3.0 & 153 \\
\hline
\end{tabular}

${ }^{* 1}$ : Not available.

${ }^{* 2}$ : First, second, and third denote 3 time measurements at each point.

$* 3$ : Measured from the mean sea level.

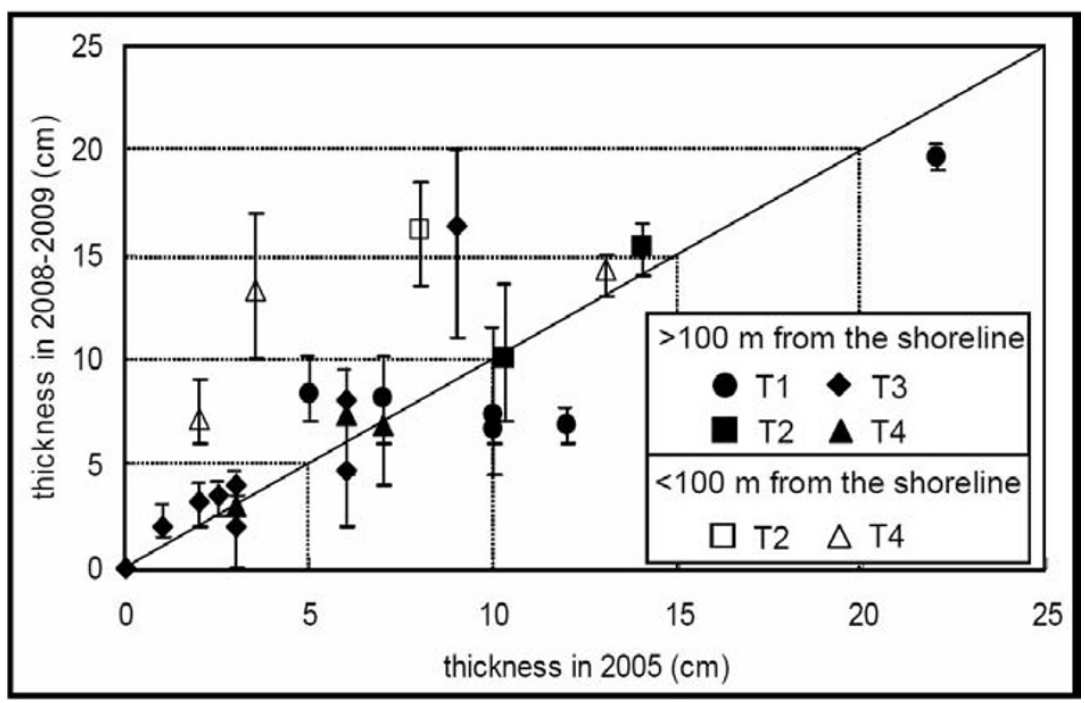

Fig. 6. Thickness of the tsunami deposits measured during 2005 and 2008 surveys. Black and white circles show the average thickness measured during the 2008 survey. The error bar shows the range of variation of the thickness for three points at each site.

sion by natural processes, although we can not exclude the possibility that it might be the result of the local variation because the difference is still minor.

The thicknesses of the tsunami deposits measured during the 2008 survey tend to be greater at three sites (T2-1, T4-1, T4-3) than those measured in the 2005 survey, even if we consider the local variation measured during the 2008 survey (Fig. 6). All these sites were located in Khao Lak and within $100 \mathrm{~m}$ from the shoreline. The tsunami flow behavior would have been very complex near the shoreline (e.g., Goto et al., 2007; Yanagisawa et al., 2009) and severe erosion and sedimentation can be expected around the beach ridge (Goto et al., 2008). Therefore, it is probable that the thickness variation near the beach ridge is greater 
than at other inland sites. Alternatively, considering that human activity has persisted at these sites (Fig. 2), we can not exclude the possibility that the thickening is attributable to human activities. Moreover, the sites are very close to the present shoreline $(<100 \mathrm{~m})$. For that reason, overwash deposits on top and behind the beach ridge might have occurred, which were reworked after the tsunami.

Regarding the preservation potential of the tsunami deposit thickness, it is noteworthy that even very thin tsunami deposits with $1 \mathrm{~cm}$ thickness in the 2005 survey (T3-2) were preserved well (Fig. 4). In addition, at no site were the tsunami deposits completely lost, probably because our studied sites, especially those where the original thickness of the tsunami deposits during 2005 survey were thin (few centimeters), were located in flat regions that did not facilitate surface water flow, and in unpopulated areas. Moreover, as shown in Fig. 6, no readily apparent trend indicates that the preservation potential of the tsunami deposit along each transect was different, suggesting that the topography at each transect is not an important factor for the sediment preservation at our studied sites. This is true probably because the topography along each transect is very flat and does not vary significantly.

Szczuciński (in press) used the following criteria to evaluate the preservation potential at Thailand: bad preservation-no deposits left or none recognizable; moderate preservation-deposits exist but they are altered in several ways; and good preservation-preserved in terms of thickness and also as structures. Based on our observations and those criteria, we judge that the preservation of the thicknesses of the tsunami deposits are moderate to good, even in tropical countries with heavy rains such as Thailand, as suggested by Szczuciński (in press).

We also found tsunami deposits near the maximum inundation limit during the 2008 survey. Their thicknesses are well consistent with those found in the 2005 survey (Fig. 1). This observation is crucially important for estimating tsunami flow characteristics using the tsunami deposits. For example, the longest landward occurrence of the tsunami deposit is regarded as the minimum inundation area of the historical or pre-historical tsunami events. Such information is useful to estimate the tsunami source model (e.g. Nanayama et al., 2003). Considering the high preservation potential implied by our results, the landward limits of the historical or pre-historical tsunami deposits are probably useful to estimate the minimum inundation area of the tsunami in cases where the area is displayed as a smooth plain with little topographic relief. However, the preservation potential might differ among places depending on the local conditions (e.g., climate, human activity, and topography). Therefore, further investigation of the preservation potential of the tsunami deposits should be conducted in many areas where local conditions differ.

\section{Conclusions}

Our results suggest that local variation of the thickness of the 2004 IOT deposits in southwestern Thailand is significant and that the tsunami deposit thickness varies by about $9 \mathrm{~cm}$ even within the narrow area because of local undulation of the topography. Our results suggest that the thickness of the tsunami deposits might be better preserved than previously thought. Therefore, the thickness of historical and pre-historical tsunami deposits can be expected to provide useful information related to the tsunami flow characteristics, although the preservation potential might differ among locations depending on local conditions. Sedimentary features and the grain size distribution might be disturbed by post-tsunami bioturbation and by various natural factors. Consequently, attention should be devoted to the use of such information to estimate tsunami flow characteristics.

Acknowledgments. We thank N. Koiwa, T. Takahashi, F. Imamura, H. Kawamata, P. Prakhammintara, and S. Sawatdiraksa for their support during our field surveys. We also thank W. Szczuciński and anonymous reviewer for their valuable suggestions. This research was supported by Japan Nuclear Energy Safety Organization. This paper is Contribution No. 15 of the Planetary Exploration Research Center, Chiba Institute of Technology.

\section{References}

Bahlburg, H. and R. Weiss, Sedimentology of the December 26, 2004, Sumatra tsunami deposits in eastern India (Tamil Nadu) and Kenya, Int. J. Earth Sci., 96, 1195-1209, 2007.

Chavanich, S., A. Siripong, P. Sojisuporn, and P. Menasveta, Impact of Tsunami on the seafloor and corals in Thailand, Coral Reefs, 24, 535, 2005.

Choowong, M., N. Murakoshi, K. Hisada, P. Charusiri, V. Daorerk, T. Charoentitirat, V. Chutakositkanon, K. Jankaew, and P. Kanjanapayont, Erosion and deposition by the 2004 Indian Ocean tsunami in Phuket and Phang-nga Provinces, Thailand, J. Coast. Res., 23, 1270-1276, 2007.

Choowoing, M., N. Murakoshi, K. Hisada, T. Charoentitirat, P. Charusiri, S. Phantuwongraj, P. Wongkok, A. Choowong, R. Subsayjun, V. Chutakositkanon, K. Jankaew, and P. Kanjanapayont, Flow conditions of the 2004 Indian Ocean tsunami in Thailand, inferred from capping bedforms and sedimentary structures, Terra Nova, 20, 141-149, 2008a.

Choowong, M., N. Murakoshi, K. Hisada, P. Charusiri, T. Charoentitirat, V. Chutakositkanon, K. Jankaew, P. Kanjanapayont, and S. Phantuwongraj, 2004 Indian Ocean tsunami inflow and outflow at Phuket, Thailand, Mar. Geol., 248, 179-192, 2008b.

Choowong, M., S. Phantuwongraj, T. Charoentitirat, V. Chutakositkanon, S. Yumuang, and P. Charusiri, Beach recovery after 2004 Indian Ocean tsunami from Phang-nga, Thailand, Geomorphology, 104, 134-142, 2009.

Dawson, A. and I. Stewart, Tsunami deposits in the geological record, Sediment. Geol., 200, 166-183, 2007.

Fagherazzi, S. and X. Du, Tsunamigenic incisions produced by the December 2004 earthquake along the coasts of Thailand, Indonesia and Sri Lanka, Geomorphology, 99, 120-29, 2008.

Feldens, P., K. Schwarzer, W. Szczucinski, K. Stattegger, D. Sakuna, and P. Somgpongchaiykul, Impact of the 2004 Indian Ocean tsunami on seafloor morphology and sediments offshore Pakarang Cape, Thailand, Pol. J. Environ. Stud., 18, 63-68, 2009.

Fujino, S., H. Naruse, A. Suphawajruksakul, T. Jarupongsakul, M. Murayama, and T. Ichihara, Thickness and grain-size distribution of Indian Ocean Tsunami deposits at Khao Lak and Phra Thong Island, Southwestern Thailand, in Tsunamiites-Features and Implications, edited by T. Shiki, Y. Tsuji, T. Yamazaki, and K. Minoura, pp. 123-132, Elsevier B.V., 2008.

Fujino, S., H. Naruse, D. Matsumoto, T. Jarupongsakul, A. Sphawajruksakul, and N. Sakakura, Stratigraphic evidence for pre-2004 tsunamis in southwestern Thailand, Mar. Geol., 262, 25-28, 2009.

Fujino, S., H. Naruse, D. Matsumoto, N. Sakakura, A. Suphawajruksakul, and T. Jarupongsakul, Detailed measurements of thickness and grainsize of widespread onshore tsunami deposit, Phang-nga Province, southwestern Thailand, Island Arc, 19, 389-398, 2010.

Goto, K., S. A. Chavanich, F. Imamura, P. Kunthasap, T. Matsui, K. Minoura, D. Sugawara, and H. Yanagisawa, Distribution, origin and transport process of boulders deposited by the 2004 Indian Ocean tsunami at Pakarang Cape, Thailand, Sediment. Geol., 202, 821-837, 2007. 
Goto, K., F. Imamura, N. Keerthi, P. Kunthasap, T. Matsui, K. Minoura, A. Ruangrassamee, D. Sugawara, and S. Supharatid, Distribution and significance of the 2004 Indian Ocean tsunami deposits: initial results from Thailand and Sri Lanka, in Tsunamiites-Features and Implications, edited by T. Shiki, Y. Tsuji, T. Yamazaki, and K. Minoura, pp. 105-122, Elsevier B.V., 2008.

Goto, K., J. Takahashi, T. Oie, and F. Imamura, Remarkable bathymetric change in a nearshore zone by the 2004 Indian Ocean tsunami: Kirinda Harbor, Sri Lanka, Geomorphology, 127, 107-116, 2011.

Hawkes, A. D., M. Bird, S. Cowie, C. Grundy-Warr, B. P. Horton, A. T. S. Hwai, L. Law, C. Macgregor, J. Nott, J. E. Ong, J. Rigg, R. Robinson, M. Tan-Mullins, T. T. Sa, Z. Yasin, and L. W. Aik, Sediments deposited by the 2004 Indian Ocean Tsunami along the Malaysia-Thailand Peninsula, Mar. Geol., 242, 169-190, 2007.

Hori, K., R. Kuzumoto, D. Hirouchi, M. Umitsu, N. Janjirawuttikul, and B. Patanakanog, Horizontal and vertical variation of 2004 Indian tsunami deposits: an example of two transects along the western coast of Thailand, Mar. Geol., 239, 163-172, 2007.

Jaffe, B. E. and G. Gelfenbaum, A simple model for calculating tsunami flow speed from tsunami deposits, Sediment. Geol., 200, 347-61, 2007.

Jankaew, K., B. F. Atwater, Y. Sawai, M. Choowong, T. Charoentitirat, M. E. Martin, and A. Prendergast, Medieval forewarning of the 2004 Indian Ocean tsunami in Thailand, Nature, 455, 1228-1231, 2008.

Kelletat, D., S. R. Scheffers, and A. Scheffers, Field signatures of the SE-Asian mega-tsunami along the west coast of Thailand compared to Holocene paleo-tsunami from the Atlantic region, Pure Appl. Geophys., 164, 413-431, 2007.

Kench, P. S., R. F. McLean, R. W. Brander, S. L. Nichol, S. G. Smithers, M. R. Ford, K. E. Parnell, and M. Aslam, Geological effects of tsunami on mid-ocean atoll islands: The Maldives before and after the Sumatran tsunami, Geology, 34, 177-180, 2006.

Kench, P. S., S. L. Nichol, S. G. Smithers, R. F. McLean, and R. W. Brander, Tsunami as agents of geomorphic change in mid-ocean reef islands, Geomorphology, 95, 361-383, 2008.

Matsumoto, D., H. Naruse, S. Fujino, A. Surphawajruksakul, T. Jarupongsakul, N. Sakakura, and M. Murayama, Truncated flame structures within a deposit of the Indian Ocean tsunami: Evidence of synsedimentary deformation, Sedimentology, 55, 1559-1570, 2008.

Matsutomi, H., T. Sakakiyama, S. Nugroho, and M. Matsuyama, Aspects of inundated flow due to the 2004 Indian Ocean tsunami, Coast. Eng. J., 48, 167-195, 2006.

Monecke, K., W. Finger, D. Klarer, W. Kongko, B. G. McAdoo, A. L. Moore, and S. U. Sudrajat, A 1,000-yaer sediment record of tsunami recurrence in northern Sumatra, Nature, 455, 1232-1234, 2008.

Moore, A., Y. Nishimura, G. Gelfenbaum, T. Kamataki, and R. Triyono, Sedimentary deposits of the 26 December 2004 tsunami on the northwest coast of Aceh, Indonesia, Earth Planets Space, 58, 253-258, 2006.

Moore, A., B. G. McAdoo, and A. Ruffman, Landward fining from multiple sources in a sand sheet deposited by the 1929 Grand Banks tsunami, Newfoundland, Sediment. Geol., 200, 336-346, 2007.

Morton, R. A., J. R. Goff, and S. L. Nichol, Hydrodynamic implications of textural trends in sand deposits of the 2004 tsunami in Sri Lanka, Sediment. Geol., 207, 56-64, 2008.

Nanayama, F., K. Satake, R. Furukawa, K. Shimokawa, B. F. Atwater, K. Shigeno, and S. Yamaki, Unusually large earthquake inferred from tsunami deposits along the Kuril trench, Nature, 424, 6606-663, 2003.

Naruse, H., S. Fujino, A. Surphawajruksakul, and T. Jarupongsakul, Fea- tures and formation processes of multiple deposition layers from the 2004 Indian Ocean Tsunami at Ban Nam Kem, southern Thailand, Island Arc, 19, 399-411, 2010.

Nichol, S. L. and P. S. Kench, Sedimentology and preservation potential of carbonate sand sheets deposited by the December 2004 Indian Ocean tsunami: South Baa Atoll, Maledives, Sedimentology, 55, 1173-1187, 2008.

Satake, K., E. A. Okal, and C. Borrero, Tsunami and its hazard in the Indian and Pacific Oceans: Introduction, Pure Appl. Geophys., 164, 249-259, 2007.

Sawai, Y., K. Jankaew, M. E. Martin, A. Prendergast, M. Choowong, and T. Charoentitirat, Diatom assemblages in tsunami deposits associated with the 2004 Indian Ocean tsunami at Phra Thong Island, Thailand, Mar. Micropaleontol., 73, 70-79, 2009.

Sugawara, D., K. Minoura, N. Nemoto, S. Tsukawaki, K. Goto, and F. Imamura, Foraminiferal evidence of submarine sediment transport and deposition by backwash during the 2004 Indian Ocean tsunami, Island Arc, 18, 513-525, 2009.

Szczuciński, W., The Post-depositional changes of the onshore 2004 tsunami deposits on the Andaman Sea coast of Thailand, Nat. Haz., doi:10.1007/s11069-011-9956-8, in press.

Szczuciński, W., P. Niedzielski, G. Rachlewicz, T. Sobczynski, A. Zioła A. Kowalski, S. Lorenc, and K. Siepak, Contamination of tsunami sediments in a coastal zone inundated by the 26 December 2004 tsunami in Thailand, Environ. Geol., 49, 321-331, 2005.

Szczuciński, W., N. Chaimanee, P. Niedzielski, G. Rachlewicz, D. Saisuttichai, T. Tepsuwan, S. Lorenc, and J. Siepak, Environmental and geological impacts of the 26 December 2004 tsunami in coastal zone of Thailand-overview of some short and long-term effects, Pol. J. Environ. Stud., 15, 793-810, 2006.

Szczuciński, W., P. Niedzielski, L. Kozak, M. Frankowski, A. Zioła, and S. Lorenc, Effects of rainy season on mobilization of contaminants from tsunami deposits left in a coastal zone of Thailand by the 26 December 2004 tsunami, Environ. Geol., 53, 253-264, 2007.

Takada, K., T. Nakata, T. Miyagi, T. Haraguchi, and Y. Nishitani, Handy Geoslicer-new soil sampler for Quaternary geologist, Chisitstu News, 579, 12-18, 2002 (in Japanese with English abstract).

Tsuji, Y., Y. Namegaya, H. Matsumoto, S. Iwasaki, W. Kanbua, M. Sriwichai, and V. Meesuk, The 2004 Indian tsunami in Thailand: Surveyed runup heights and tide gauge records, Earth Planets Space, 58, 223 232, 2006.

Umitsu, M., C. Tanavud, and B. Patanakanog, Effects of landforms on tsunami flow in the plains of Banda Aceh, Indonesia, and Nam Khem, Thailand, Mar. Geol., 242, 141-153, 2007.

Yanagisawa, H., S. Koshimura, K. Goto, T. Miyagi, F. Imamura, A. Ruangrassamee, and $\mathrm{C}$. Tanavud, The reduction effects of mangrove forest on a tsunami based on field surveys at Pakarang Cape, Thailand and numerical analysis, Estuar. Coast. Shelf Sci., 81, 27-37, 2009.

Yawsangratt, S., W. Szczuciński, N. Chaimanee, R. Jagodzinski, S. Lorenc, S. Chatprasert, D. Saisuttichai, and T. Tepsuwan, Depositional effects of 2004 tsunami and hypothetical paleotsunami near Thap Lamu Navy Base in Phang Nga Province, Thailand, Pol. J. Environ. Stud., 18, 17-23, 2009.

K. Goto (e-mail: kgoto@perc.it-chiba.ac.jp), J. Takahashi, and S. K.
Fujino 